\title{
Varia
}

\section{Conference Proceedings: Workshop on the "Manifesto on European Criminal Policy", Madrid, 9th April 2010}

\author{
Marta Muñoz de Morales Romero*
}

A colloquium to discuss the recently published Manifesto on European Criminal Policy was held in Madrid, at the Residencia de Estudiantes, on 9th April 2010 ${ }^{1}$. The majority of the members of the European Criminal Policy Initiative were present at the meeting, along with Spanish governmental and judicial authorities and academics from various countries.

The session began with a brief presentation of the Manifesto by both Prof. Helmut Satzger (Ludwig-Maximilians-University, Munich, Germany) and Adán Nieto Martín (Castilla-La Mancha-University, Ciudad Real, Spain). The presentation was followed by the first round-table discussion chaired by Prof. Luis Arroyo Zapatero. Alongside him were Álvaro Cuesta (Member of Parliament, President of the Justice Committee), Soledad Mestre (Ambassador on a special mission for Internal European Union Security) and Pedro Crespo Barquero (Prosecutor from the General Secretariat of the Office of the State Prosecutor). They all highlighted the need to rely on a series of recognized criminal principles at European level that should also be of importance for the implementation of community regulations by national authorities. There was unanimity in relation to the difficulties and achievements of the Spanish legislator for the correct transposition of the framework decisions. In particular, Pedro Crespo pointed out that the Spanish legislator had decided not to incorporate the crime of 'virtual' child pornography contained in the framework decision on child pornography, on the basis that no "legal good" was infringed. Likewise, he indicated that the introduction of criminal responsibility for legal persons was already a reality following the latest reform of the criminal Code.

The second round-table, chaired by Prof. Luis María Díez Picazo, discussed the principles of subsidiarity and coherence. Prof. Katalin Ligeti from the University of Luxemburg and Prof. John Vervaele from the University of Utrecht opened the discussion. Both speakers criticised the Manifiesto's limited scope of application and the decision to chose only the configuration of the limits of criminal policy, leaving to one side its objectives. The Manifesto was conceived for the harmonization of

\footnotetext{
* Instituto de Derecho penal europeo e internacional. This report has been prepared within the framework of the research project of the Junta de Comunidades de Castilla-La Mancha PC 108-0144-0952 under the title "El espacio europeo de seguridad y justicia y los nuevos desafios para la protección penal de los derechos humanos en la globalización [The European area of Freedom Justice and Security and the new challenges for the criminal protection of human rights in a globalized world".

${ }^{1}$ See www.crimpol.eu/.
} 
criminal provisions, i. e. the approximation of substantive criminal law. However, European criminal policy is a much wider concept that should include not only the definition of behaviours and sanctions to be imposed by the , but also the regimes for mutual cooperation, for victim protection, for the penitentiary system, etc. Furthermore, European criminal policy has to achieve certain objectives that should also be defined earlier on, in order to evaluate their efficacy. During the following discussion Prof. Maria Kaiafa-Gbandi and other members of the ECPI-group made the point that European criminal policy evidently covers more fields than a simple approximation of criminal provisions. However, in the Group's point of view, material criminal law is the basis upon which one must begin to approach the other questions. For that reason, the Manifesto rejects any type of instrumental relation between material criminal law and procedural criminal law and prefers, in consequence, a minimalist approach because, in the words of Prof. Kaiafa-Gbandi, "the research has to start somewhere". Prof. Vervaele insisted that if the Group had decided to go "step by step", it should specify as much in the Manifesto. Equally the members of ECPI indicated that if the decision had been taken to place limits on criminal intervention, it was because this had always been the starting point for the configuration of material criminal law.

In relation to the principle of subsidiarity, Prof. Ligeti pointed out that in reality the Manifesto limited itself to reproducing the 'double test' envisaged in the Treaty of the European Community (and now also in the Treaty on the Functioning of the $\mathrm{EU})$ to verify its compliance with that principle. This test consists in demonstrating, in the first place, that the objectives of the proposed action may not be reached by the Member States, and in proving, in second place, that actions at the level of the Union may achieve them better. This test has been used since the inclusion of the principle of subsidiarity in the Treaty of Maastricht in 1992; nevertheless this did not entail a reduction of the European Union's legislation. This is why according to Prof. Ligeti, this test could not effectively limit Community interventions in criminal law. Nevertheless, this view was challenged given the new possibilities offered by the Treaty of Lisbon, as the European Court of Justice will have competency to judge subsidiarity in the case of criminal regulations, and national parliaments will be able to activate the early warning procedure to block a community regulation, whenever a certain number of legislative state assemblies consider that it does not respect the principle of subsidiarity. As a counter-argument, Prof. Ligeti argued, that the jurisdictional power of the ECJ would depend considerably on the formal motivating requirements as to the added value of the legislative proposal which were expected from the European legislator and, fundamentally, the European Commission, when presenting their proposals. The absence in the Manifesto of specific criteria of a quantitative and qualitative nature that would help to verify whether the principle of subsidiarity is upheld was a further criticism noted at the round-table, which was very well received by some members of the Group. In consequence, Prof. Maria Kaiafa suggested the possibility of incorporating an addi- 
tional protocol in the Manifesto to include this type of indicator with more and better examples.

With regard to the principle of coherence, Prof. Ligeti criticised the categorization of coherence as a "legal principle" - an incoherence that Prof. Vervaele and Díez Picazo also shared. In their opinion, it is more of a philosophical concept. Moreover, even if it were a "legal principle", it should be taken into account that coherence cannot only be determined - as the Manifesto appears to do - by the degree or, if you prefer the quantum, of punishment that the European legislator demands from the member States when transposing their community obligations into national law. There are other factors that are even more decisive such as the rules that govern conditional freedom or the design of the penitentiary system itself, which can be more or less flexible or rigid when complying with the penalties. The ECPI-members Thomas Elholm from the University of Denmark and Peter Asp from the University of Stockholm, who took part in the round-table debate, responded that coherence is a "legal principle" because criminal Law is built upon values that are nurtured by the proportional relation of the penalties applicable to different offences in accordance with their seriousness and because it is a determining factor in avoiding unequal treatment between citizens of the different Member States. The problem, Prof. Picazo noted, is that it is very difficult to determine which situations are equal and which are unequal. All the more so if, as Prof. Ligeti pointed out, the system of application and execution of the penalties varies considerably from one to another.

Finally, reference was made to the relation of complementarity between the principles of subsidiarity and coherence. This relation - it was said - could lead to a paradoxical situation that had not been taken into account by the Manifesto: the principle of subsidiarity acts as a brake on Community interventions but also as justification to intervene in more and more fields. In consequence, the coherence of European policies may function as a parameter that will favour greater centralization.

In the second round table, the principles of proportionality and legality were discussed. In relation to the principle of proportionality, Prof. Martin Böse of the University of Bonn (Germany) criticized the Manifesto for determining the concept of fundamental legitimate interest as an interest provided for in the primary law of the Union. With this approach, the concept is considerably limited because the action of the Union is restricted by the principle of the attribution of competences. In this respect, competence should not be confused with the legitimate purpose. As an example of the latter, the speaker referred to the directive on money laundering. This regulation was adopted in the framework of the competences that the Union exercises to protect the common market and to guarantee the stability of the financial markets. However, the legitimate purpose in criminal terms can neither be identified in this competence nor can it - consequently - be identified in the funding Treaties, because the purpose of the criminal offence of money laundering is to deprive the criminal of illicitly gained assets and this interest is not envisaged in 
Community Law. In second place, Prof. Böse indicated that the use of criminal law as a means of protecting the efficacy of administrative law may in some instances be justified, as for example in the case of legislation relating to the transport of military armaments. In third place, the speaker made reference to the problems that arise in the Union over compliance with the principle of proportionality. The obligation that falls on the Member States to transpose the Community norms can cause inconsistencies in the European criminal law system, as the European legislator might have respected the principle of criminal proportionality, but the Member States - when implementing the regulation - may go beyond what it specified and be even more punitive. The reason for this incoherence is due to the minimum obligations established in the framework decisions and directives: the States can always go further than the minimum standards with regard to the definition of offences and sanctions envisaged in the Community provisions, thereby infringing the principle of proportionality.

With respect to the principle of legality, Prof. Francesco Viganò of the University of Milan (Italy) made reference to the reserve of the law. In his opinion, the frequently repeated discussion on the democratic deficit from which the EU suffers when introducing criminal law should be overcome. If it was true that the procedure to adopt decisions followed under the Third Pillar was not sufficiently democratic, because no institution that represented the public played a role in it, this situation has been completely changed by the co-decision procedure, as the European Parliament together with the Council now have a relevant decisionmaking role. This is why the discussion on the reserve of the law does not centre so much on the democratic problem, but more on the reluctance of the Member States to cede sovereignty to a supranational institution in such an especially sensitive field as criminal law. The States oppose any encroachment of their sovereignty in criminal matters because criminal law affects above all their constitutional traditions. However, the speaker noted that matters considered especially sensitive such as abortion, are practically impossible to harmonize as they have no cross-border dimension. And, moreover, although that was the case, normally the framework decisions usually establish clauses that give States a margin of appreciation so as not to punish certain behaviours as criminal offences. On the principle of determination, Prof. Viganò reproduced examples from the Manifesto, in which he criticised a lack of determination in the criminal definition of certain behaviours by the European legislator. This is the case of the framework decision on racism and xenophobia that fails to describe what should be understood by behaviour that is "likely to disturb public order".

The last person to speak at the second round-table was Prof. Antonio Cuerda Riezu from the Rey Juan Carlos University of Madrid (Spain). The speaker assessed the Manifesto in very positive terms and advised its drafters to offer a more exhaustive explanation of the rules of good government and the inclusion of specific references to the principle of individual criminal responsibility and strict liability. Likewise, he considered it advisable that the Manifesto refers to the problems that arise with 
blanket criminal laws. This last suggestion was contested by Prof. Satzger who understood that responsibility for avoiding or at least for making limited use of blanket laws lay with the national and not the European legislator.

Prof. José Luis de la Cuesta of the University of the Basque Country chaired the last round-table. He recommended the inclusion in the Manifesto of a reference to the principle of humanity. Such a mention would imply not only a limitation on the European legislator in terms of the prohibition of torture and the use of inhuman or degrading treatment, for example, but also the acceptance of such principles as resocialization and activation of the rights of victims in criminal proceedings.

The next topic for discussion was the principle of culpability. Prof. Eduardo Demetrio Crespo of the University of Castilla-La Mancha (Spain) and Prof. Anabela Rodrigues of the University of Coimbra (Portugal) both intervened and both agreed on two criticisms. In the first place, they indicated that although it could be implicitly deduced from the Manifesto that the principle of culpability acted as a limit on criminal intervention, it was advisable to indicate this specifically, because otherwise the difference between culpability and prevention might be confused at a dogmatic level. In second place, they recommended a specific rejection of systems of strict liability along the lines of the Anglo-Saxon systems.

In relation to the criminal liability of legal persons, Prof. Rodrigues expressed satisfaction with the approach of the Manifesto, as the criteria for extending criminal liability to firms may only be developed with the consent of the member States. Thus, some European countries - inter alia Portugal and Spain - have been introducing this type of provision in their respective criminal codes to comply with the community commitments.

On the concept of guilt, Prof. Demetrio pointed out that one may not resort solely and exclusively to a normative concept; on the contrary, attention should be paid, in its definition, to social, cultural and historic connotations, etc. everywhere and at all times.

In the debate, the principle of human dignity was stressed as the foundation of guilt. However, Prof. Nieto intervened to point out that perhaps it would be a good idea to establish a clear definition between the guilt of natural persons, the foundation and limits of which should indeed be human dignity, and the guilt of legal persons, the foundation for which could never be the same as in the latter case.

As a conclusion, the participants at the Madrid workshop showed great support for the idea of the Manifesto, though there was some disagreement and criticism as to the details. The ECPI-members promised that the discussion will go on and that all contributions will be taken into account. 